\title{
CORRECTION
}

\section{Correction: A balance score between immune stimulatory and suppressive microenvironments identifies mediators of tumour immunity and predicts pan-cancer survival}

Tolga Turan, Sarah Kongpachith, Kyle Halliwill, Jessica Roelands (iD, Wouter Hendrickx, Francesco M. Marincola, Thomas J. Hudson, Howard J. Jacob, Davide Bedognetti, Josue Samayoa and Michele Ceccarelli

British Journal of Cancer (2021) 124:1340; https://doi.org/10.1038/s41416-020-01193-w

Correction to: British Journal of Cancer (2020); https://doi.org/ 10.1038/s41416-020-01145-4, published online 5 November 2020

Since the publication of this paper the authors have noticed an error in the name of Wouter Hendrickx, where Dr. Hendrickx's name was incorrectly listed as Wouter Hendricks. This has been corrected above.

\begin{abstract}
Open Access This article is licensed under a Creative Commons Attribution 4.0 International License, which permits use, sharing, adaptation, distribution and reproduction in any medium or format, as long as you give appropriate credit to the original author(s) and the source, provide a link to the Creative Commons license, and indicate if changes were made. The images or other third party material in this article are included in the article's Creative Commons license, unless indicated otherwise in a credit line to the material. If material is not included in the article's Creative Commons license and your intended use is not permitted by statutory regulation or exceeds the permitted use, you will need to obtain permission directly from the copyright holder. To view a copy of this license, visit http://creativecommons. org/licenses/by/4.0/.
\end{abstract}

(c) The Author(s) 2020 